\title{
PENINGKATAN KEMAMPUAN MENULIS PUISI SISWA DENGAN TEKNIK PEMODELAN
}

\author{
Eny Ratnawati, S.Pd \\ SMP Negeri 5 Sungai Raya, Kabupaten Kubu Raya \\ Email: enyratnawati68@gmail.com
}

\begin{abstract}
One of the problems in the world of education today is the low quality of education caused by several factors including the low quality of learning caused by the ability of teachers who are still lacking, not using methods that are in accordance with the material being taught, an evaluation system that is not appropriate, and the ability of teachers. in learning activities is still lacking because the learning strategies carried out by teachers are still monotonous. Modeling technique is a learning concept that can help teachers improve students' writing skills so that they can be applied in their lives as family and community members. The purpose of this Classroom Action Research $(C A R)$ is to determine the extent to which learning through modeling techniques improves the poetry writing skills of class VIII B students at SMP Negeri 5 Sungai Raya. In this Classroom Action Research (CAR) carried out in 2 cycles, from the results of the actions taken, the modeling technique is proven to be able to improve students' poetry writing skills in Indonesian lessons by reaching the KKM standard of 70 . From $64.46 \%$ in cycle I, it can increase to $78.75 \%$ in cycle 2 . The results of this action research show that learning Indonesian through modeling techniques is effective and can improve the poetry writing skills of class VIII B students at SMP Negeri 5 Sungai Raya.
\end{abstract}

\section{Keywords: Modeling Techniques, Writing Poetry}

\section{INTRODUCTION}

The government through the Ministry of National Education has made a learning foundation, namely the Education Unit Level Curriculum (KTSP) or also known as the 2006 Curriculum. In the Regulation of the Minister of National Education of the Republic of Indonesia Number 22 of 2006 concerning Content Standards for Elementary and Secondary Education Units page 58 it is stated that Indonesian Language Subject Competency Standard is a minimum ability qualification of students that describes mastery of knowledge, language skills, and positive attitudes towards Indonesian Language and Literature.

Then, the purpose of learning Indonesian subjects in general is for students to have the following abilities: 1) Communicate effectively and efficiently in accordance with applicable ethics, both orally and in writing. 2) Appreciate and be proud to use Indonesian as the language of unity and the language of the state. 3) Understand Indonesian and use it appropriately and creatively for various purposes. 4) Using the Indonesian language to improve intellectual abilities, as well as emotional and social maturity. 5) Enjoy and utilize literary works to broaden horizons, refine character, and improve knowledge and language skills. Lastly, 6) appreciate and be proud of Indonesian literature as the cultural and intellectual treasures of Indonesian people.

Then, the Competency Standards for Indonesian Language Subjects are; 1) Students can develop their potential according to their abilities, needs, and interests, and can grow appreciation for the literary works and intellectual output of the nation itself. 2) Teachers can focus on developing students' 
language competencies by providing various language activities and learning resources. 3) Teachers are more independent and flexible in determining linguistic and literary teaching materials according to the conditions of the school environment and the abilities of their students. 4) Parents and the community can be actively involved in the implementation of language and literature programs in schools. 5) Schools can arrange educational programs on language and literature according to students and available learning resources. 6) Regions can determine materials and sources for learning language and literature in accordance with regional conditions and peculiarities while still taking into account national interests.

Based on the syllabus for class VIII semester II with writing competency standards, namely expressing thoughts and feelings in free poetry, there are two basic competencies, namely: a) writing free poetry by using appropriate word choices, and b) writing free poetry by taking into account the elements of rhyme.

The results of preliminary observations carried out by researchers in the implementation of Indonesian language learning at SMP Negeri 5 Sungai Raya, especially writing free poetry for class VIII experienced problems which can be stated as follows. 1) Students have difficulty finding ideas. 2) Students have difficulty determining the first words in the poem. 3) Students have difficulty in developing poetry ideas because of the lack of vocabulary. 4) Students have difficulty writing poetry because they are not or are not used to expressing their feelings, thoughts and imagination in poetry. Finally, 5) there is a misguided theory in writing poetry that must depart from the theme.

The problems above arise because learning to write poetry is still teacher centered. This means that most teachers still dominate teaching and learning activities with a monotonous lecture method approach, so that students are given lectures on poetry theory rather than the practice of writing poetry. Then, students have not been given guidance in writing poetry as a whole, coherently and gradually, even though learning to write poetry is a process as well as a product.

Various methods have been used by schools and teachers to overcome the above problems, among others: 1) Implement writing poetry based on direct objects. In this method, students write poetry based on the objects they see directly. Students are invited outside the classroom to see objects they like and then write them down into poetry. 2) Write a poem based on the story. In this method, students write poetry based on the stories they read. After that, students were asked to write poetry based on the stories they read. However, these efforts have not been maximized, so that students' poetry writing skills have not increased, students' scores have not reached the KKM that has been set. This is certainly inseparable from the role and approach implemented by the teacher in the teaching and learning process. The learning approach still applies expository patterns so that students have not learned optimally. This learning model approach causes the teacher to be more active while the students seem passive and only accept what the teacher gives, so this will hinder students' creativity.

This kind of learning has the characteristics of being teacher-centered, the approach used is expository, the teacher dominates the process of learning activities in the classroom, the exercises provided are more routine. Learning activities are boring because so far students see that writing poetry is difficult, so many students are 'averse' to follow the learning. The result of all the problems above is the low achievement of students and the lack of student interest in learning to write poetry. This can be seen in the final average score of class VIII B students in writing poetry on the last daily test, which is 61.96. This means that it has not reached the expected value of 70 .

Based on the preliminary observations that have been stated above, what should be done and pursued by schools, especially teachers so that these problems can be overcome, especially efforts to overcome difficulties in carrying out the learning 
process of writing poetry so that the results are in accordance with what is expected. Therefore, a change is needed in learning to write poetry. The changes in question mainly concern the approach or learning model that is carried out in learning to write poetry, so that writing poetry becomes a fun learning, so that it can increase motivation and facilitate students' understanding in expressing their creative ideas in the form of poetry.

The selection of learning models and methods that are in accordance with the curriculum objectives and student potential are basic abilities and skills that must be possessed by a teacher. This is based on the assumption that the teacher's accuracy in choosing learning models and methods will affect the success and ability of students to write poetry, because the learning models and methods used by the teacher affect the quality of the learning activities they carry out.

Seeing the condition of learning activities at SMP Negeri 5 Sungai Raya today, it is still colored by the emphasis on the knowledge aspect and there is still little that refers to the involvement of students in the learning process itself. Meanwhile, the process of learning to write poetry does not stimulate students to be actively involved in the teaching and learning process. In addition, learning activities in learning to write poetry carried out by teachers have not been able to foster a learning culture among students. In turn, it will have a significant effect on the acquisition and ability of students to write poetry.

From here, the teacher may feel that he is teaching well, but his students are not learning, so there is a misconception between the teacher's understanding of teaching and the target and mission of Indonesian as an important subject. This condition is supported by the reality in the field, that the methodological aspects and expository approach dominate all learning activities. Therefore, learning to write poetry in Indonesian subjects has not been able to foster a climate that challenges students to learn and does not support the productivity and development of students' thinking.
In addition to being able to arouse students' interest, the approach or method chosen by the teacher must be able to increase the student's psychological activity and awareness that in fact he is able to write poetry and is skilled at writing poetry creatively. Learning to write poetry should not only be done by transferring knowledge to students, but also by helping students to express their creative ideas in the form of poetry. In this regard, efforts to improve the quality of learning activities in learning to write poetry is a very urgent need to be done. Therefore, we need a learning technique in writing poetry that is considered appropriate to overcome the difficulties mentioned above.

Taking into account the current condition of learning to write poetry at SMP Negeri 5 Sungai Raya, and from various thoughts as described above, it is deemed necessary to improve learning to write poetry. This is based on the aim of improving poetry writing skills, so the realization of the learning process in the classroom must try to change the image that learning Indonesian, especially writing poetry is easy and boring learning, into fun learning.

Writing is one of the four language skills (listening, speaking, reading, and writing). Writing skill is a process of how to communicate ideas to others well, so that others can understand what is conveyed through writing. Tarigan $(2008$, p.3) states "writing is a language skill that is used to communicate indirectly, not face to face with other people".

Meanwhile, Kusmayadi (2007, p.3) says "writing is processing thoughts, sharpening feelings, and communicating the results of thoughts and sharpening thoughts in the form of writing / essays. Writing can also be said to be an activity of expressing or giving birth to thoughts and feelings through writing. In line with that, Susetyo $(2009$, p. 1) said "writing is an activity to give birth to thoughts or feelings". Then, Triton (2011, p.19) explains "it is in the writing process that we can explore fresh ideas that can be put into writing. The idea can come from experience, imagination, from rationality or reasonable 
thinking. Finally, Semi (2003, p.4) said "writing is an activity of recording spoken language into written language".

Through some of the opinions above, it can be concluded that writing is an activity to pour ideas, ideas, opinions into written form. Writing is one aspect of skills in learning Indonesian Language and Literature. Therefore, through writing activities, students are expected to be able to express their creative ideas. These creative ideas can be like poetry, short stories, articles and other scientific works.

Regarding the meaning of poetry, too many definitions of poetry have been given by experts. Between one with the other are different. Therefore, it is very difficult to limit the meaning of poetry. However, efforts in the interests of education and teaching, especially for learning appreciation of literature in the classroom, need boundaries, definitions, and clarity of conventions.

A poem as Pradopo, (1993, p.7) explains "poetry can be seen from its elements in the form of: emotion, imagination, thought, idea, tone, rhythm, five sense impressions, word order, figurative words, density, and mixed feelings". Then, Nurgiyantoro (2005, p.28) states "a form of literary work is called poetry if it includes the utilization of various languages to achieve the effect of beauty. The language of poetry is certainly short and dense, with few words, but dialogues something more." Then Budiman, (2008, p.168) said "poetry is a meeting between the inner world of the individual and the inner world of nature". That is, a personal appreciation of nature.

While the definition of modeling technique is to make the work of a person as a model to create a new work, or imitate the work of someone who is used as a model to create a new work. Contextual approach (CTL) component modeling means that in a particular skill or knowledge learning, there is a model that can be imitated. (Depdiknas, 2002, p.16)

Meanwhile, Marahaimin (1994, pp. 2021) suggests this modeling with the term copy the master which means imitating the painting of an expert. Here, Marahaimin gives an example of how a person learns to paint by imitating the painting of an expert so that as much as possible, as closely as possible, after ten or twenty tries, the learner will get a new master to imitate, and so on.

In line with that, Senduk and Nurhadi (2003, p.50) argue that modeling or modeling techniques is one of the seven components of contextual learning. That is, in a particular skill or knowledge learning, there is a model that can be imitated. Modeling basically discusses the ideas being thought of, demonstrating how the teacher wants his students to learn and doing what the teacher wants his students to do. Modeling can be in the form of demonstrations, giving examples of concepts or learning activities. In other words, "the model can be in the form of how to operate something, how to pronounce a word", (Trianto, 2012, p.84). That way, the teacher provides a model on how to learn.

Furthermore, Nuryatin (2010, p.34) states that modeling can be interpreted as an effort to provide models (examples) related to the material and learning activities carried out by students. Modeling must be done in a planned manner in order to contribute to the understanding and involvement of students in the learning process, so that the ability to write poetry has increased. Modeling is said to be effective if students become more aware of the material being studied, are more enthusiastically involved, provide variety of situations, cost and time are more efficient.

The selection of modeling components in Indonesian language and literature learning is an effort to improve poetry writing skills and change students' behavior in a positive direction from not being interested in being in love with poetry. The requirements of a good model are relevant to the needs of students, according to the level of students, interesting, practical, functional, challenging, and rich in action.

The existence of a model in learning will help students to think critically. Students will be helped by observing the model provided, so that students better understand the material being taught. Students not only receive 
information from the teacher, but students can also explore information from the provided model.

Based on the description above, it can be concluded that the modeling technique is part of the contextual approach. Modeling technique is a knowledge or skill that can be demonstrated or there is a model that can be imitated. The model is not only fixed on the teacher or student, but the model can be seen and heard by someone.

Another opinion on closer modeling is that Logan (1971, p.15) states that most children have natural feelings for something poetic. They like to listen to beautiful sounds, the similarities of the sounds, the rhythms generated by the poetry readers. They are even happy and can replace the words of a poem or song with other words according to the pattern of the poems and songs they have heard.

\section{RESEARCH METHODS}

The subject of this research is the ability to write poetry of students in Indonesian lessons at SMP Negeri 5 Sungai Raya. Based on the observations made by the researchers, the students of class VIII B of SMP Negeri 5 Sungai Raya were lacking the ability to write poetry in Indonesian lessons. This research is a classroom action research, which is carried out in stages until it gets the desired results. This Classroom Action Research was conducted on class VIII B students, with a total of 28 students; 11 female students and 17 male students.

\section{RESULTS AND DISCUSSION}

\section{Results}

Cycle 1

The implementation of teaching and learning activities for cycle 1 was carried out on September 9 to October 16, 2019 at SMP Negeri 5 Sungai Raya with a total of 28 students. In this case the researcher acts as a teacher. The teaching and learning process refers to the lesson plans that have been prepared.
Observation (observation) is carried out simultaneously with the implementation of teaching and learning. At the end of the teaching and learning process, students are given to write poetryl with the aim of knowing the level of success of students in the teaching and learning process that has been carried out. The data from the research results in cycle 1 can be explained that the application of modeling techniques obtained the percentage of students' learning completeness scores for writing Indonesian language poetry is $64.46 \%$ of students who have completed learning. These results indicate that in the first cycle classically students have not finished studying, because the desired completeness is 70 according to the KKM value. This is because students still feel new and do not understand what the teacher means and uses by using modeling techniques.

The implementation of teaching and learning activities for cycle 2 was carried out on October 23 to November 30, 2019 at SMP Negeri 5 Sungai Raya for the 2019-2020 school year. In this case the researcher acts as a teacher. The teaching and learning process refers to the lesson plan by paying attention to revisions in cycle 1 , so that mistakes or deficiencies in cycle 1 do not occur again in cycle 2. Observations are carried out simultaneously with the implementation of teaching and learning.

At the end of the teaching and learning process, students are given to write poetry with the aim of knowing the level of success of students in the teaching and learning process that has been carried out. The instrument used is writing poetry.

Based on the data obtained, the percentage value of writing poetry is $78.75 \%$ classically, the learning mastery that has been achieved is 70 , according to the KKM value. The results in cycle 2 have improved better than cycle 1. An increase in the ability to write poetry in cycle 2 is influenced by an increase in the teacher's ability to apply modeling techniques, so that students become more accustomed to learning like this so that 
students are easier to understand the material being taught. has been given.

Based on the results of this study indicate that the application of learning models with modeling techniques has a positive impact in improving students' poetry writing skills. $64.46 \% ; 78.75 \%$. On cycle 2 student learning completeness classically has been achieved.

\section{Discussion}

Based on data analysis, it was found that the students' activities in the learning process with modeling techniques in each cycle increased. This has a positive impact on students' poetry writing skills, which can be shown by increasing the average score of students in each cycle which continues to increase.

Based on the results of the research above, the students' ability to write poetry for Indonesian language lessons by applying modeling techniques is very good. This can be seen in every meeting of 28 students at the time this research was conducted with an average score of $64.46 \%$ and $78.75 \%$, respectively.

Based on the 2013 Curriculum, students are said to be complete if they have achieved the KKM standard score of 70. Meanwhile, in this study, those achieving a score of 70 in (cycle 2) have been achieved according to the targets set in the 2013 Curriculum. Thus, the proposed hypothesis can be accepted.

\section{CONCLUSION AND SUGGESTION Conclusion}

From the results of learning activities that have been carried out for two cycles, and based on all the discussions and analyzes that have been carried out, it can be concluded as follows: 1.Learning by applying modeling techniques in improving students' poetry writing skills at SMP Negeri 5 Sungai Raya Indonesian subjects marked with increasing student learning completeness in each cycle, namely; $64.46 \%$ and $78.75 \%$. 2. The application of modeling techniques in Indonesian lessons has a positive influence, namely it can improve students' poetry writing skills. 3. The application of modeling techniques can improve the teaching materials that have been received by students so far, so that they feel ready to face the next learning.

\section{Suggestion}

From the research results obtained from the previous description so that the teaching and learning process in junior high schools (SMP) is more effective and provides optimal results for students, the following suggestions are submitted: 1. To implement modeling techniques requires sufficient preparation, so that teachers must be able to determine or choose a topic that can really be applied by providing modeling techniques to obtain optimal results. 2. In order to improve students' poetry writing skills, teachers should train students more often with discovery activities, even in simple abilities, where students will be able to discover new knowledge, acquire concepts and skills, so that students are successful or able to solve problems that they faced.

\section{REFERENCES}

Abidin., \& Hasanudin, Z. (2002). Survey Dengan GPS. Jakarta: Pradnya Paramita.

Arikunto, S. (2007). Prosedur Penelitian Suatu Pendekatan Praktek. Jakarta: Rineka Cipta

Burhan, N. (2005). Penilaian Pengajaran Bahasa. Yogyakarta: BPFE.

Chandra, B. (2008). Metodologi Penelitian Kesehatan. Jakarta: EGC.

Waluyo, H.J. (1987). Teori dan Apresiasi Puisi. Jakarta: Erlangga

Kusmayadi, T. (2007). Pengaruh Relatinship Quality terhadap Loyalitas. Nasabah Tabungan, STIE STAN Indonesia mandiri, Jepara.

Ismail, M. (1994). Menulis Secara Populer. Jakarta: Pustaka Jaya 
Newman., \& Logan. (1971). Strategy Policy and Central Management. London and New York. Longman.

Nurhadi., \& Gerrad, S.A. (2003). Pembelajaran Kontekstual (Contextual Teaching and Learning/CTL) Dan Penerapannya Dalam KBK. Malang: Penerbit Universitas Universitas Negeri Malang.

Nuryatin., \& Agus. (2010). Mengabadikan Pengalaman dalam Cerpen. Rembang: Yayasan Adhigama.

Pradopo. (1993). Pengkajian Puisi. Yogyakarta: Gadjahmada. University Press.

Tarigan, H.G. (2008). Membaca Sebagai Suatu Keterampilan Berbahasa. Bandung: Angkasa
Trianto. (2012). Model Pembelajaran Terpadu. Jakarta: PT Bumi Aksara.

Triton, P. (2011). Manajemen SDM dalam Organisasi Publik dan Bisnis. Bandung: Alfabeta.

Semi, M.A. (2003). Menulis Efektif. Padang: Angkasa Raya.

Susetyo, B. (2009). Handout Materi Pembelajaran: Kajian Seni Pertunjukan. Semarang. Unnes Press Pustaka Pelajar

Depdiknas. (2006). Kurikulum Tingkat Satuan Pendidikan. Jakarta: Depdiknas.

Permendikbud Nomor 64 tahun (2013).Tentang Standar Isi Pendidikan. Dasar dan Menengah. Jakarta: Kementerian Pendidikan dan Kebudayaan. Kemendikbud. 